\title{
An Examination Of The Effects Of The February, 2001 Crisis (Turkey) On The Performances Of The Low-Q And High-Q Firms
}

Ece C. Karadagli, (E-mail: ece@ cankaya.edu.tr), Cankaya University, Turkey Tolga Omay, (E-mail: omayt@yahoo.com), Cankaya University, Turkey

\begin{abstract}
This paper examines the effects of the February 2001 Economic Crisis (Turkey) on the low- $Q$ and high-Q firms. In the study, our sample is composed of the firms that are actively being traded on Istanbul Stock Exchange (ISE) during that time, and is divided into two sub-samples based on their Tobins' $Q$ values. As firms with high Tobins' $Q$ values are supposed to have lower debt levels we proposed them to be less affected by the crises: their debt repayment commitments are lower, although they are expected to be under the burden of higher interest rates. On the other hand, low-Q firms have incentives to overinvest due to the high levels of available free cash and they may be under the burden of some perquisites expenses. But because of the asset substitution affect, the investments undertaken by low- $Q$ firms are expected to be safer projects while high-Q firms may have undertaken more risky projects. To test our hypothesis that the crisis would affect the low- and high-Q firms to differing extends, we construct the average mean excess returns of both sub-samples and use the Large Sample Test of Hypothesis About a Population Mean method. Our results mainly confirm our expectations: we found that the average mean excess negative returns of high- $Q$ firms were higher than that of low- $Q$ firms during the February 2001 Crisis, indicating that high- $Q$ firms are more riskier in an economic crisis setting than low- $Q$ firms, which in turn implies that the effects of the conflict between equityholders and debtholders dominate the affects of the conflict between managers and the shareholders.
\end{abstract}

\section{INTRODUCTION}

1

$\mathrm{n}$ this paper, we attempt to examine the effects of the February, 2001 Crisis on the market excess returns of the low-Q and the high-Q firms and to analyze whether this disturbance to the market have different affects on each group of firms. Low-Q firms can be defined as mature and slow-growth firms with relatively large free cash flows and limited positive net present value (NPV) project opportunities whereas high-Q firms are supposed to be young firms with relatively limited cash flows but have good investment opportunities for growth.

Tobins' Q can be defined as the ratio of the firm's market value to the replacement cost of its assets. Tobin argued that firms with Q-ratios greater than one (high-Q firms) have an incentive to invest as for them capital equipment is worth more than its costs to replace and they will stop investing only when Q-ratio falls below one (low$\mathrm{Q}$ firms) as after this point equipment is worth less than its replacement cost. But due to the agency problems a low-Q firm may tend to have an incentive to overinvest.

Free Cash Flow Hypothesis (Jensen 1986) relates the agency problem between managers and shareholders over the distribution of free cash flows generated by the firm. It proposes that managers have pecuniary or nonpecuniary incentives to overinvest in the firm by using its free cash flows to accept negative NPV projects rather 
than distributing these cash flows to shareholders. Jensen and Meckling (1976) argues that there are two types of agency conflict specifically; the conflict between managers and shareholders and the conflict between debtholders and equity holders.

The conflict between managers and shareholders arises from the fact that when managers hold less than hundred percent of the firms residual claims, they do not capture the entire gain from their profit enhancement activities although they do bear the entire cost of these activities. Hence, they overindulge in consuming 'perquisities' relative to the level that would maximize the firm value. They argue that this inefficiency is negatively related to the fraction of the firm's equity owned by the manager and debt increases the manager's share of the equity, holding the manager's absolute investment in the firm constant. Moreover, Jensen (1986) points that as debt commits the firm to pay out cash, it reduces the free cash available to managers to engage in 'perquisities' consuming activities. In other words, debt payments reduce free cash flow. Consistent with the above argument, Lang and Litzenberg (1989) showed that low-Q firms tend to overinvest while high-Q firms can be referred as value-maximizing firms. Since low-Q firms are expected to have more free cash flows with limited growth opportunities, it is a reasonable prediction. Moreover, Slutz (1990) argued that firms that have good investment opportunities are expected to hold lower debt levels relative to the mature, slow growth and cash-rich firms. These arguments lead the conclusion that firms for which slow or even negative growth is optimal and that have large cash inflows from operations, i.e. for the so called Low-Q firms, are expected to have more debt.

The conflict between debtholders and equityholders arises from the fact that debt gives equity holders and incentive to invest suboptimally. Since, if an investment turns out to be a successful one equityholders capture the gain, and if it fails, because of limited liability, debtholders bear the costs, equityholders can undertake high risk projects, which in turn decrease the value of the debt. Thus, equityholders can benefit from undergoing very risky projects, even if they are value-decreasing. Brander and Lewis (1986) confirm this argument stating that leverage creates an incentive to invest in risky projects. But, according to Jensen and Meckling, if the debtholders can anticipate equityholders' future behavior, they can pass this cost to the equityholders. This affect is generally referred as the 'asset substitution effect'. Diamond (1989) argued that because of the asset substitution problem, a firm can obtain low interest debt only through convincing the debtholders that it only invests in safe, positive NPV projects. The firm can manage this through holding a clean default history. The longer a firm's clean default history, the stronger its reputation. Thus, it is reasonable to expect the older, more established firms to find choosing safe projects optimal while young firms may choose risky projects.

The above argument contains some implications to expect the extend of the affects of the crisis to be different for low-Q and high-Q firms. First, firms with lower debt levels, that are expected to be high-Q firms, are supposed to be less affected from the crises as their debt repayment commitments are lower, although they are expected to be under the burden of higher interest rates. Second, as low-Q firms have incentives to overinvest due to the high levels of available free cash, they may have under the burden of some perquisites expenses that are contracted previously. But because of the asset substitution affect, the investments undertaken by low-Q firms are expected to be safer projects while high-Q firms may have undertaken more risky projects. Hence, because of their different cash outflow commitments and their investment projects' differing natures, we expect the low- and high-Q firms to be affected from the crisis in differing degrees. If our expectations hold, results of this study may serve as an additional helpful hint for the investors to assess the relative riskiness of the firms based on the high- and low-Q classification of the firms. It may also shed light to whether the affects of the conflict between managers and shareholders or the affects of the conflict between equityholders and debtholders dominate under a crisis setting. But it is important to note that crises with different natures may cause different factors to operate or may cause the same factors to operate differently in the market.

\section{DATA AND METHODOLOGY}

Our sample consists of the firms that are actively being traded on the Istanbul Stock Exchange (ISE). After excluding financial sector institutions and firms which have missing data problem as well as those with negative owners' equity values from our sample, we end up with a final sample size of 194 firms. All the data used in the analyses are taken from FINNET. 
For the purposes of the study, in order to divide our sample into two sub-samples based on their corresponding Tobin's Q values which are calculated for each of the firms in our sample by using the below formulation:

Tobins' Q Value $^{1}=\quad$ Short-Term Debts + Long-Term Debts + (Number of Outstanding Shares x Adjusted price $\left.{ }^{2}\right)$ Owners' Equity

Based on the calculated $\mathrm{Q}$ values, we had to separate the high- and low-Q firms according to the median value of 4.508459, because there were only two firms with Tobins' $Q$ value below one. Finally we end up with two samples, namely Low-Q Firms and High-Q Firms, each containing 97 firms. Then, we calculated the average mean excess returns for each sample for the period $[-5,+5]$ of the date of the crises; February $19^{\text {th }}, 2001$.

To calculate the average mean excess returns, first we obtained the closing prices of each firm and the market index, ISE100 for the 10 day period $[-5,+5]$. Then we calculated the returns using the formula:

$\mathrm{R}_{\mathrm{i}}=\left[\mathrm{R}_{\mathrm{i},(\mathrm{t})}-\mathrm{R}_{\mathrm{i},(\mathrm{t}-1)]}\right] / \mathrm{R}_{\mathrm{i},(\mathrm{t}-1)}$

Next, we calculated the mean excess returns for each firm with the formula:

$\operatorname{MER}_{\mathrm{i}}=\Pi\left(\mathrm{R}_{\mathrm{i}, 5}+1\right)\left(\mathrm{R}_{\mathrm{i},-4}+1\right) \ldots . .\left(\mathrm{R}_{\mathrm{i},+5}+1\right)-\Pi\left(\mathrm{R}_{\mathrm{m},-5}+1\right)\left(\mathrm{R}_{\mathrm{m},-4}+1\right) \ldots . .\left(\mathrm{R}_{\mathrm{m},+5}+1\right)$

And as a final step to construct our full data base, we calculated the mean excess returns for each sub-sample by:

Average $\mathrm{MER}_{\mathrm{Low}-\mathrm{Q} \text { Firms }}=\sum \mathrm{MER}_{\mathrm{i} \text { (Low-Q firms) }} /$ sample size (97)

Average $\mathrm{MER}_{\text {High-Q Firms }}=\sum \mathrm{MER}_{\mathrm{i} \text { (High-Q firms) }} /$ sample size (97)

Our results are summarized at the table below:

\begin{tabular}{|l|c|c|c|}
\hline Sample & N & Average MER* & St. Deviation \\
\hline Low-Q Firms & 97 & -0.08028 & 0.154837 \\
& & $(5.1064)$ & 0.195506 \\
\hline
\end{tabular}

* Z-values are in parentheses: Both mean values are statistically significant at $99 \%$ confidence level.

According to the hypothesis testing; we construct our null hypothesis as: The average mean excess returns of low- and hing-Q firms are equal. And, our alternative hypothesis is constructed as: The average mean excess returns of low- and high-Q firms are not equal. To test our hypothesis we employed "Large Sample Test of Hypothesis About a Population Mean"

\section{FINDINGS}

Z-value (based on Low-Q firms) ${ }^{3}$ is found to be greater than 1.645 with $90 \%$ confidence interval $(\alpha=0.10)$. Thus, our null hypothesis is rejected. Hence, average mean excess returns of low- and high-Q firms are found to be statistically different at $90 \%$ confidence interval.

The results of the study mainly confirm our expectation that low- and high-Q firms' stock returns are affected at differing degrees from the February 2001 Crisis. Although a 10\% significance level can be interpreted as only

\footnotetext{
${ }^{1}$ All the numbers are obtained as of June 30, 2000.

${ }^{2}$ As we could not obtain unadjusted prices we had to work with the adjusted prices instead.

${ }^{3} \mathrm{Z}=|-0.080228-(-0.10663)| /\left(0.154837 / 97^{1 / 2}\right) \approx 1.6762$
} 
marginally significant, a $2.635 \%$ difference in the average mean excess returns of the low- and high-Q firms which are both found to be statistically significantly different than zero at $99 \%$ confidence level, indicates a notable difference in monetary terms. Furthermore, it is seen that the average mean excess return of high-Q firms are effected $2.635 \%$ more than that of low-Q firms, which may imply that the riskiness of the undertaken investment projects are assessed to be more important by investors than the debt structure of the firms in the firm valuation. In other words, our results imply that the affects of the conflict between equityholders and debtholders dominate the affects of the conflict between managers and the shareholders. This conclusion stems from the fact that low-Q firms are supposed to have more debt while they undertake safer investment projects whereas high-Q firms are supposed to hold less debt while they may go for riskier investment projects. Overall, our results indicate that high-Q firms are more riskier in an economic crisis setting than low-Q firms.

\section{CONCLUSION}

We found that the average mean excess negative returns of high-Q firms were higher than that of low-Q firms during the February 2001 Crisis. This result pinpoints that the riskiness of the undertaken projects are assessed to be a more important determinant of the relative riskiness of firms under a crisis setting, because the high-Q firms, by definition, hold less debt but have an incentive to invest in riskier projects. But, this conclusion requires more empirical support. In addition, in our study the debts of the firms are not analysed based on the short- and long-term debt distinction. As there may be a possibility that investors interpret short-term debts more risky than long-term debts, such a distinction may change our results or can open another window for future studies.

It would be worthy to note a problem regarding the methodology we used; we had to separate the high- and the low-Q firms based on the median value, as there were only two low-Q firms with $\mathrm{Q}$ values lower than one. So, generalization of our results with respect to high- and low-Q firms lacks some confidence from this perspective.

The final point we want to note is that the February 2001 Crisis was arguably an unexpected crisis. Although the timing of the crisis was more unexpected, there was an expectancy of a crisis in general among the public. Thus, under wholly unexpected crisis, our results may deviate. This points also needs further investigation as it is important to note that crisis with different natures may cause different factors to dominate the scene or may cause the same factors to play different roles.

\section{REFERENCES}

1. Brander, James A. and Lewis, Tracy R., Oligopoly and Financial Structure: The Limited Liability Effect American Economic Review 66, pg. 956-970, 1986.

2. Brealey, Richard A. and Myers, Stewart C., Principles of Corporate Finance, McGrow-Hill Inc., 1991.

3. Diamond, Douglas W., Reputation Acquisition in Debt Markets, Journal of Political Economy 97, pg. 828-862, 1989.

4. Fama, Eugene F. Agency Problems and The Theory of The Firm, Journal of The Political Economy 88, pg. 288307,1980 .

5. Harris, Milton and Raviv, Arthur, The Theory of The Capital Structure, The Journal of Finance 46, pg. 297-355, 1991.

6. Howe, Keith M., He, Ja, and Kao, G., Wenchi, One-Time Cash Flow Announcements and Free Cash Flow Theory: Share Repurchases and Special Dividends, Journal of Finance, 47, pg.1963-1975, 1992.

7. Jensen, Michael C., Agency Cost of Free Cash Flow, Corporate Finance and Takeover, American Economic Review, pg. 323-329, 1986.

8. Jensen, Michael C. and Meckling, William, Theory of Firm: Managerial Behavior,Agency Costs and Capital Structure, Journal of Financial Economics 3, pg. 305-360, 1976.

9. Lang, L. and Litzenberger, R., Dividend Announcements: Cash Flow Signalling vs. Free Cash Flow Hypothesis? Journal of Financial Economics 24, pg. 181-191, 1989.

10. Stulz, Rene, Managerial Discretion and Optimal Financing Policies, Journal of Financial Economics 26, pg. 3-27, 1990. 